\title{
Valentino Kuzelj
}

Student

Pravni fakultet Sveučilišta u Zagrebu

E-mail: valentino.kuzelj01@gmail.com

\section{SOCIJALNI KARAKTER NORMATIVNOG UREĐENJA STUDENTSKOG RADA U REPUBLICI HRVATSKOJ ${ }^{1}$}

\author{
UDK / UDC: $331.5-057.87$
}

JEL klasifikacija / JEL classification: J21, J28, J88

DOI: $10.17818 /$ EMIP/2020/2.10

Pregledni rad / Review

Primljeno / Received: 30. ožujka 2020. / March 30, 2020

Prihvaćeno za tisak / Accepted for publishing: 7. prosinca 2020. / December 7, 2020

\section{Sažetak}

Značajan udio mladih u nekom je trenutku studija zaposlen, te je potrebno jasno definirati ciljeve $i$ konkretne politike sa svrhom osiguranja dostojnoga životnog standarda mladih i stvaranja materijalnih preduvjeta nesmetanom izvršavanju studentskih obveza $i$ završetku studija. Studentski rad predstavlja važan izvor studentskih prihoda u Republici Hrvatskoj te je koncem 2018. godine donesen novi Zakon o obavljanju studentskih poslova s ciljem unaprjeđenja studentskog standarda. Iako proklamirano kao nedvojbeno socijalna mjera, zakonsko rješenje nedostatno je zaštitilo studente, tretirajući ih kao prekarne radnike. Pritom je pretjerano blago fiskalno opterééenje, proizišlo iz povezanih propisa, učinilo studentski rad atraktivnijim i isplativijim od rada iz radnog odnosa, kreirajući latentnu opasnost poremećaja tržišta rada. U radu se ukazuje na konkretne probleme normativnog uređenja studentskog rada u Republici Hrvatskoj te ističe potreba njegova redefiniranja s ciljem ostvarenja socijalne pravednosti.

Ključne riječi: studentski rad, radnik, tržište rada, oporezivanje, socijalna pravda.

\section{UVOD}

Mogućnost studentskog rada kao socijalna mjera usmjerena poticanju rasta studentskog standarda, temeljena na individualnoj akciji, proklamira interese pripadnika studentske populacije kao raison d'être predmetnog normativnog uređenja. Deklarativna predanost hrvatskog zakonodavca takvom cilju izražena je

\footnotetext{
${ }^{1}$ Autor posebno zahvaljuje izv. prof. dr. sc. Sonji Cindori i doc. dr. sc. Ani Horvat Vuković s Pravnog fakulteta Sveučilišta u Zagrebu na svoj pomoći i savjetima prilikom pisanja rada. Također, autor zahvaljuje dvama anonimnim recenzentima na vrijednim komentarima i sugestijama.
} 
koncem 2018. godine uzdizanjem uređenja studentskog rada na zakonsku razinu, donošenjem Zakona o obavljanju studentskih poslova (u nastavku: ZOSP). Dotad je ta materija bila definirana aktom podzakonske snage, Pravilnikom o posredovanju pri zapošljavanju redovitih studenata koji se, uz nekoliko manjih izmjena nevažnih interesu ovoga rada, besprekidno primjenjivao od 1996. godine. $^{2}$ Valja napomenuti kako je uređenje mogućnosti studentskog rada i starije od navedenih dokumenata te potječe još iz vremena socijalizma. U nastavku će se posvetiti isključivo određenim prijepornim pitanjima pozitivno-pravnog uređenja studentskog rada u Republici Hrvatskoj (u nastavku: RH), imajući na umu da su neka od njih postojala i u ranijim uređenjima predmetne materije.

U tom smislu, svrha ovoga rada ne počiva na analizi novoga zakonskog uređenja, o čemu je u relativno kratkom razdoblju njegova važenja objavljeno nekoliko relevantnih radova (Iljazović, 2018; Opalić, 2018; Trbojević, 2018; Vidović, 2018; Zlatović \& Galić, 2018), već u postavljanju dviju teza o učincima aktualnog uređenja studentskog rada u RH. Prva teza ističe kako, usprkos proklamiranoj zaštiti interesa studentske populacije, normativno uređenje predmetne materije ne rezultira podizanjem studentskog standarda, već latentnom prijetnjom smanjenja konkurentnosti pojedinih kategorija radnika ${ }^{3}$ te kreira mogućnost ozbiljnih poremećaja na tržištu rada. Isplativost studentskog rada proizlazi iz neznatne opterećenosti studentskih primanja doprinosima te (u najmanju ruku blagim) poreznim tretmanom njihovih prihoda, što omogućuje poslodavcima da im isplate (u neto iznosu) veću plaću, a da pritom ukupno plate manje nego bi za isti rad platili radniku (u bruto iznosu) temeljem radnog odnosa. Time studenti zaposleni preko studentskog ugovora potencijalno raspolažu s više (neto) dohotka nego što bi bio slučaj ako bi isti posao obavljali temeljem radnog odnosa, a troškovi koje snosi poslodavac u konačnici su niži. Pritom se ističe i opasnost prikrivanja radnoga odnosa studentskim ugovorom. Druga teza ukazuje kako krajnje liberalan režim uređenja studentskog rada ne predstavlja socijalnu mjeru, s obzirom da ne uzima u obzir negativne aspekte zaposlenja u odnosu na studentske obveze. Ističe se opasnost produbljivanja socio-ekonomskog jaza između studenata koji dolaze iz dobrostojećih obitelji i onih koji su prisiljeni raditi radi osiguranja egzistencije.

$\mathrm{S}$ ciljem dokazivanja iznesenih teza, prije nego se pristupi analizi rada temeljem ZOSP-a, u drugom će se poglavlju na općenitoj razini razmatrati važnost prihoda od rada za studente te njegova učestalost u RH. U trećem će se poglavlju pokušati iznaći načela kojima se zakonodavac vodio prilikom normiranja studentskog rada. U četvrtom će se poglavlju analizirati narav studentskog rada u odnosu na radni odnos u hrvatskom zakonodavstvu, dok će se

\footnotetext{
${ }^{2}$ Otvaranje mogućnosti studentskog rada izvanrednih studenata te određivanje minimalne satnice isticane su najvećim novinama u vrijeme donošenja ZOSP-a (Čavar, 2018: 64). Druge odredbe uvelike su naslijeđene iz prethodnih uređenja.

${ }^{3}$ Potražnja za studentskim radom raširena je u različitim sektorima, a najčešće se navode poslovi telefonske prodaje, korisničke podrške, tajnički poslovi, ali je potražnja značajna i u uslužnom sektoru poput prehrane i smještaja. Također, posljedice ekonomske krize iz 2008. godine odrazile su se i na povećanje studentskog rada na poslovima maloprodaje (Čavar, 2018: 65).
} 
u petom poglavlju pristupiti usporedbi pojma „radnik“ u praksi Suda Europske unije (u nastavku: Sud EU) i studenta (izvođača) definiranog ZOSP-om. Potom će se u šestom poglavlju analizirati (ne)opravdanost značajnog iznosa oslobođenja studentskog rada od fiskalnih davanja te će se istaknuti potencijalni učinak takvih mjera na tržište rada u cjelini. Naposljetku, u sedmom će se poglavlju postaviti pitanje primjerenosti zakonskog uređenja ostvarenju socijalne pravednosti. U zaključnim će se razmatranjima istaknuti potreba za redefiniranjem normativnog okvira obavljanja studentskih poslova u RH, u svrhu ostvarenja stvarnog povećanja studentskog standarda te uklanjanja latentne prijetnje poremećaja tržišta rada stvorene ZOSP-om. Takvim izmjenama otvorit će se put pomirenju studentske dobrobiti i međugeneracijske pravednosti.

\section{MOTIVI I ZNAČAJ RADA UZ STUDIJ U HRVATSKOM KONTEKSTU}

U RH, ali i drugim zemljama regije, godinama izražena niska potražnja na tržištu rada i obeshrabrenost u pronalazak zaposlenja, uzrokovali su povlačenje mladih s tržišta rada: duljim ostankom u sustavu obrazovanja ili u skupini mladih koja ne traži zaposlenje, ne obrazuje se ili osposobljava (Obadić, 2017: 130). Visoke stope nezaposlenosti mladih u RH predstavljaju snažan poticaj upisivanju studija, s obzirom da mladi nisu suočeni s dilemom studiranja ili sudjelovanja na tržištu rada, već studiranja ili potencijalno dugotrajne nezaposlenosti (Čavar, 2018: 63). Mogućnost rada uz studij, kao potencijalno važan izvor sredstava, zasigurno pridonosi odluci o nastavku obrazovanja. Zbog toga valja razmotriti udio rada uz studij na općenitoj razini u RH, prije nego se pristupi analizi mogućnosti studentskog rada temeljem ZOSP-a.

U prosjeku $70 \%$ studenata na području istraživanja EUROSTUDENT-a ${ }^{4} \mathrm{u}$ nekom je trenutku studija i zaposleno. Pritom je oko $51 \%$ zaposleno u razdoblju trajanja predavanja (engl. lecture period). Otprilike $35 \%$ studenata ima plaćeni posao tijekom cijelog razdoblja predavanja, dok ih oko $16 \%$ radi povremeno, a približno $20 \%$ radi samo tijekom razdoblja u kojima nema predavanja (engl. lecture-free period) (Hauschildt, Vögtle \& Gwosć, 2018: 132133). Većina zaposlenih studenata (oko $69 \%$ ) glavnim razlogom rada uz studij ističe potrebu za dodatnim financijskim sredstvima radi pokrića životnih troškova te svaki drugi student smatra kako mu je taj prihod neophodan za studiranje, dok svaki peti radi kako bi pridonio uzdržavanju drugih (članova obitelji i sl.). Pritom, $\mathrm{u}$ prosjeku troje od pet zaposlenih studenata kao jedan od motiva rada uz studij navode stjecanje radnog iskustva. Također, proizlazi značajna povezanost između socioekonomskog statusa studenta i potrebe za studentskim radom te se studenti iz dobrostojećih obitelji češće zapošljavaju kako bi stekli radno iskustvo u budućem zvanju, dok je dodatni financijski prihod primarni razlog zaposlenja

\footnotetext{
${ }^{4}$ Više o EUROSTUDENT-u vidi na https://www.eurostudent.eu/about
} 
starijih studenata, studenata koji žive odvojeno od roditelja te onih čiji roditelji nisu visokoobrazovani (Oertelè, 2019).

U RH je nešto manje od polovice studenata $(42,3 \%)$ zaposleno $\mathrm{u}$ razdoblju predavanja. Dok otprilike četvrtina studenata $(26,4 \%)$ radi tijekom cijelog razdoblja predavanja (engl. regular paid jobs), a 15,9\% njih plaćene poslove obavlja povremeno (engl. occasional paid jobs). Nasuprot tome, u razdobljima u kojima nema predavanja zaposleno je više od polovice studenata $(55,2 \%)$. Pritom petina studenata $(20,8 \%)$ radi u razdobljima predavanja i bez predavanja tj. tijekom cijele godine. Otprilike trećina studenata $(34,2 \%)$ nema plaćeni posao, neovisno radi li se o razdoblju predavanja ili bez predavanja (detaljnije vidi u Tablici 2.). U pogledu motiva, gotovo tri četvrtine studenata navodi potrebu rada radi pokrića životnih troškova $(74,6$ \%), a gotovo polovica ističe $(44,3 \%)$ kako si bez posla uz studij ne bi mogli priuštiti studiranje. Također, $26 \%$ ističe potrebu zaposlenja radi pridonošenja uzdržavanju drugih. Značajno je da velik broj studenata $(65.9 \%)$ među motivima rada uz studij navodi stjecanje radnog iskustva. U usporedbi s navedenim prosjecima zemalja EUROSTUDENT-a, u određenim je kategorijama moguće uočiti odstupanja podataka za RH od nekoliko postotnih bodova, dok u određenim kategorijama gotovo nema odstupanja.

Tablica 1.

Udio zaposlenosti studenata u RH u odnosu na razdoblja (bez) predavanja

\begin{tabular}{|l|c|}
\hline Studenti zaposleni tijekom razdoblja predavanja (engl. lecture period) & $\mathbf{4 2 , 3 \%}$ \\
\hline $\begin{array}{l}\text { Studenti zaposleni tijekom cijelog razdoblja predavanja } \\
\text { (engl. regular paid jobs) }\end{array}$ & $26,4 \%$ \\
\hline $\begin{array}{l}\text { Studenti zaposleni povremeno tijekom razdoblja predavanja } \\
\text { (engl. occasional paid jobs) }\end{array}$ & $15,9 \%$ \\
\hline $\begin{array}{l}\text { Studenti zaposleni u razdobljima bez predavanja } \\
\text { (engl. lecture-free period) }\end{array}$ & $\mathbf{5 5 , 2} \%$ \\
\hline
\end{tabular}

Izvor: Izrada autora, prema: EUROSTUDENT VI Database (pristup: 16. 5. 2020.).

Tablica 2 .

Detaljan pregled udjela zaposlenosti studenata $\mathrm{u}$ RH u odnosu na razdoblja (bez) predavanja

\begin{tabular}{|l|r|}
\hline Studenti zaposleni samo tijekom razdoblja predavanja & $5,7 \%$ \\
\hline Studenti povremeno zaposleni samo tijekom razdoblja predavanja & $4,9 \%$ \\
\hline Studenti zaposleni tijekom razdoblja predavanja i razdoblja bez predavanja & $20,8 \%$ \\
\hline $\begin{array}{l}\text { Studenti povremeno zaposleni tijekom razdoblja predavanja i bez } \\
\text { predavanja }\end{array}$ & $11,1 \%$ \\
\hline Studenti zaposleni samo tijekom razdoblja bez predavanja & $23,3 \%$ \\
\hline Studenti koji ne rade & $34,2 \%$ \\
\hline
\end{tabular}

Izvor: Izrada autora, prema: EUROSTUDENT VI Database (pristup: 16. 5. 2020.). 
Tablica 3 .

Zastupljenost određenih motiva za rad uz studij kod studenata $\mathrm{u} \mathrm{RH}^{5}$

\begin{tabular}{|l|c|}
\hline Pokriće životnih troškova & $74,6 \%$ \\
\hline Stjecanje radnog iskustva & $65,9 \%$ \\
\hline Bez plaćenog posla ne bi si mogao/la priuštiti studiranje & $44,3 \%$ \\
\hline Pridonošenje uzdržavanju drugih & $26 \%$ \\
\hline
\end{tabular}

Izvor: Izrada autora, prema: EUROSTUDENT VI Database (pristup: 16. 5. 2020.).

Unatoč tome, nezanemariva je činjenica kako gotovo dvije trećine studenata u RH (barem povremeno) radi uz studij, dok tri četvrtine onih koji rade navodi takvu zaradu potrebnom za pokriće životnih troškova. Evidentno je kako rad uz studij predstavlja važan izvor prihoda hrvatskih studenata. Pritom, valja uzeti u obzir kako su osobe koje studiraju uz rad suočene s manjom vjerojatnošću završetka studija, što proizlazi iz vremenskog opterećenja zaposlenih studenata. Nužno je primijetiti socijalnu nejednakost u strukturi zaposlenih studenata, s obzirom da većina dolazi iz obitelji niskog socioekonomskog statusa te je rad uz studij uzrokovan potrebom pokrivanja životnih i troškova studija, a ne željom za razvojem vještina i znanja u svrhu povećanja konkurentnosti u budućem zanimanju. Zbog toga zaposleni studenti spadaju u osjetljivu skupinu (Bežovan, Puljiz, Šućur, Babić, Dobrotić, Matković \& Zrinščak, 2019: 496). To je posebno apostrofirano činjenicom da $70 \%$ studenata zaposlenih tijekom cijelog razdoblja predavanja (Tablica 4.) u prosjeku radeći provede preko dvadeset sati tjedno, što zasigurno utječe na njihov raspored vremena i izvršavanje studentskih obveza te potencijalno predstavlja prepreku završetku studija.

Tablica 4.

Udio studenata zaposlenih tijekom cijelog razdoblja predavanja (engl. regular paid jobs) prema prosječno tjedno provedenim satima rada

\begin{tabular}{|l|c|}
\hline $1-5$ sati rada tjedno & $3,6 \%$ \\
\hline $6-10$ sati rada tjedno & $8,1 \%$ \\
\hline $11-15$ sati rada tjedno & $5,9 \%$ \\
\hline $16-20$ sati rada tjedno & $12,4 \%$ \\
\hline$>20$ sati rada tjedno & $70 \%$ \\
\hline
\end{tabular}

Izvor: Izrada autora, prema: EUROSTUDENT VI Database (pristup: 16. 5. 2020.).

Imajući navedeno u vidu, mogućnost rada putem studentskog ugovora reguliranu ZOSP-om, uz to što predstavlja fleksibilan način ostvarenja studentske zarade, valja promatrati u svjetlu socijalnih efekata na studente, ali i na tržište rada u cjelini. S time na umu, u nastavku će se pristupiti analizi hrvatskog modela

\footnotetext{
${ }^{5} \mathrm{U}$ istraživanju je korištena skala od 1 do 5 , pri čemu 1 označava potpuno slaganje (engl. applies totally), a 5 potpuno neslaganje (engl. does not apply at all). Zbog preglednosti rada ovdje se navode samo združeni (engl. aggregated) odgovori 1 (potpuno slaganje, engl. applies totally) i 2 (slaganje, engl. applies) na svaki od ponuđenih motiva, detaljnije vidi EUROSTUDENT VI Database: http://database.eurostudent.eu/
} 
normativnog uređenja obavljanja studentskih poslova, ne bi li se iznašao odgovor na pitanje o njegovu (ne)socijalnom utemeljenju te stvarnim i potencijalnim učincima takve regulacije.

\section{JE LI MOGUĆE IZVESTI NAČELA NA KOJIMA JE UTEMELJENO ZAKONSKO UREĐENJE OBAVLJANJA STUDENTSKIH POSLOVA?}

RH je Ustavom uspostavljena kao demokratska i socijalna država (Ustav Republike Hrvatske, u nastavku: URH, čl. 1., st. 1.), a socijalna pravda (čl. 3.) izdignuta je među najviše vrednote ustavnopravnoga poretka kao temelj za tumačenje Ustava. Socijalna prava proizašla iz opredijeljenosti hrvatskog ustavotvorca socijalnim vrijednostima zahtijevaju aktivno državno postupanje s ciljem ispravljanja neželjenih učinaka djelovanja tržišnih mehanizama te osiguranja minimuma socijalne sigurnosti građana, a osobito slabijih i ugroženih skupina (Smerdel \& Sokol, 2009: 105).

Ustavni sud RH u više je predmeta definirao značenje i doseg ustavnoga koncepta socijalne države i načela socijalne pravde kao obveze zakonodavca na uspostavljanje socijalno pravednoga poretka. Promatrano s aspekta ekonomske neutralnosti demokratskoga ustava, koji se ne priklanja nijednoj ekonomskoj doktrini, proizlazi kako modaliteti ostvarenja socijalno pravednoga poretka pripadaju zakonodavčevoj normativnoj diskreciji (Cindori \& Kuzelj, 2019: 834835). Imajući na umu takvu zakonodavčevu obvezu, valja pokušati iznaći načela kojima se vodio prilikom donošenja ZOSP-a te potom pristupiti analizi usklađenosti konkretnog zakonskog rješenja s trajnim i temeljnim vrijednostima socijalne države i pravde.

Iako ZOSP eksplicite ne navodi načela vlastita utemeljenja, iz obveza posrednika pri obavljanju studentskih poslova kojima mu se nameće dužnost podupiranja zastupljenosti studenata na tržištu rada „radi razvoja studentskog standarda“ (čl. 9., st. 3.) te istovremeno određuje da poslove posredovanja mora obavljati „tako da ne izazove poremećaje na tržištu rada i ne ugrozi prava radnika“ (čl. 9., st. 2.), proizlazi kako je namjera zakonodavca prilikom normiranja studentskog rada bila nedvojbeno socijalno orijentirana. Tako se temeljnim načelom, implicite sadržanim u zakonskom tekstu i zakonodavčevoj namjeri, može smatrati unaprjeđenje studentskog standarda, s time da ono ne smije dovesti do poremećaja tržišta rada i ugroze prava radnika.

Nažalost, ostatak zakonskog teksta u potpunosti ignorira ta prešutno prihvaćena načela inkorporirana u odredbe o posredovanju te bi se ZOSP u svojoj primjeni mogao pokazati kao krajnje nesocijalna mjera, suprotna duhu ustavnoga 
koncepta socijalne države. $^{6} \mathrm{U}$ tom cilju u nastavku će se pristupiti analizi prijepornih pitanja uređenja studentskog rada.

\section{SADRŽAJNO RAZLIKOVANJE UGOVORA O RADU, UGOVORA O DJELU I STUDENTSKOG UGOVORA PREMA BITNIM ODREDNICAMA RADNOGA ODNOSA}

Iako ugovor o radu predstavlja temeljni institut ugovornog radnog odnosa, postoji mnoštvo oblika zapošljavanja i obavljanja određenih poslova koji posjeduju sve odrednice rada, ali se njihovo obavljanje ne temelji na ugovoru o radu tj. ne zasniva se radni odnos (Zlatović \& Malenica, 2016: 26; Herman \& Ćupurdija, 2011: 98). U tom smislu Potočnjak i Gotovac (2009: 280) uočavaju svojevrsnu dihotomiju pravnih oblika rada: s jedne strane radni odnos, a nasuprot tome sve ostale oblike rada zasnovane određenim drugim pravnim odnosima, a ne radnim. Među potonjima valja istaknuti ugovor o djelu te studentski ugovor koji je moguće smatrati derivatom ugovora o djelu. Pritom su ti ugovori visoko prekarni jer se na njih ne primjenjuje zaštita radničkih prava iz Zakona o radu (u nastavku: ZR) (Butković, Samardžija, Skazlić \& Čavar, 2018: 42). Stoga valja napraviti uvodnu distinkciju između osobe u radnom odnosu, osobe koja radi temeljem ugovora o djelu te osobe zaposlene temeljem studentskog ugovora.

ZR (čl. 4., st. 1.) definira radnika kao fizičku osobu koja u radnom odnosu obavlja određene poslove za poslodavca te propisuje (čl. 7., st. 1.) obvezu poslodavca radniku dati posao te mu isplatiti plaću, a na strani radnika obvezu osobnog obavljanja preuzetog posla. U navedenim su odredbama sadržane bitne odrednice radnoga odnosa: subordinacija, naplatnost i obveza osobne činidbe rada, dok posljednja (dobrovoljnost) proizlazi iz ustavne slobode rada i prava na slobodan odabir zaposlenja (URH, čl. 55.), a uz to je esencijalna svakom ugovornom odnosu (detaljnije vidi Herman \& Ćupurdija, 2011: 90-91). Navedene odrednice radnog odnosa važne su zato što ,postaju differentia specifica toga rada u odnosu na svaki drugi rad" te se radom izvan radnog odnosa može smatrati svaki pravni odnos s predmetom rada, a kojem nedostaje koja od bitnih sastavnica (Potočnjak \& Gotovac, 2009: 280).

Ugovorom o djelu, s druge strane, ne zasniva se radni odnos, već se njime jedna strana (izvođač) obvezuje obaviti određeni posao, a druga strana (naručitelj) platiti mu za to naknadu (Zakon o obveznim odnosima, čl. 590.). Takav ugovor karakterizira činjenica da izvođač umjesto plaće prima ugovorenu

\footnotetext{
${ }^{6}$ Također, ovdje valja istaknuti i odnos odredaba ZOSP-a o posredovanju te ustavnih vrijednosti poduzetničkih i tržišnih sloboda, a koje su nemalo ograničene definiranjem uskoga kruga potencijalnih posrednika pri obavljanju studentskih poslova (vidi čl. 7. ZOSP-a). Također, nameće se pitanje (ne)dovoljne transparentnosti trošenja doprinosa iz čl. 12., st. 1., t. 3.-4., koje je posrednik dužan trošiti u namjenski zakonom predviđene svrhe (vidi čl. 14. ZOSP-a). Ocjena opravdanosti navedenoga prelazi potrebe ovoga rada te se ovdje samo naznačuje.
} 
naknadu te nepostojanje klasične subordinacije iz radnog odnosa, a pritom nije bitna sama činidba rada već rezultat rada (Milković, 2016: 691). Također, kod ugovora o djelu nije nužno sadržana obveza osobne činidbe rada te ju izvođač može povjeriti trećoj osobi (Butković et al., 2018: 43). Kako bi se spriječila zlouporaba ugovora o djelu za prikrivanje radnoga odnosa, zakonodavac je ZRom (čl. 10., st. 1.) propisao da će se, ukoliko poslodavac sklopi ugovor za obavljanje posla koji prema naravi i vrsti rada te ovlasti poslodavca odgovara obilježjima posla iz radnoga odnosa, smatrati da je sklopljen ugovor o radu. Pritom se teret dokaza suprotnoga prebacuje na poslodavca. Iz toga proizlazi da: „ako radnik svakodnevno izvršava radne zadatke, te zadatke dobiva od poslodavca (dakle prisutan je element subordinacije) i za to dobiva mjesečnu plaću - tad je nedvojbeno riječ o ugovoru o radu, a ne o ugovoru o djelu neovisno kako je nazvan“ (Milković, 2016: 692). U usporedbi sa studentskim ugovorom, ističe se činjenica da studenti ne mogu raditi bez naknade, dok se kod ugovora o djelu može ugovoriti naknada za rezultat rada, a ne sam rad (Butković et al., 2018: 43).

U pogledu studentskog ugovora, na početku valja uočiti dvojnu narav tako zaposlene osobe, koja je ujedno student i „radnik“. Za potrebe uređenja studentskog rada dostatnom se pokazala isključivo formalna definicija pojma „studenta“ (vidi ZOSP, čl. 2, t. 1-2.). Ista je u skladu s pojmovnim određenjem ponuđenim u Zakonu o znanstvenoj djelatnosti i visokom obrazovanju (u nastavku: ZZDVO, čl. 86., st. 1.) koji propisuje da se status studenta stječe „upisom na sveučilište, veleučilište ili visoku školu“. Student kao „radnik“ ZOSP-om (čl. 2., t. 4.) je definiran kao „,izvođač“ koji je s „,naručiteljem posla“ (poslodavcem) i ,posrednikom“ sklopio ugovor o obavljanju studentskog posla te za naručitelja obavlja taj posao. Do problema pri smještanju tako zaposlenih studenata u kategoriju pravnih odnosa izvan radnog odnosa dolazi zbog činjenice da „zbog naravi njegova sadržaja rad studenata obično odgovara radu koji se obavlja temeljem standardnih ugovora o radu“, s jedinom razlikom (obično) kraćega trajanja (Butković et al., 2018: 43). Naplatnost, kao bitan element radnog odnosa, prisutna je i kod studentskog ugovora (ZOSP, čl. 11., st. 2.). Nadalje, ZOSP (čl. 13., st. 1.) obvezuje studenta na osobno obavljanje preuzetog posla prema uputama poslodavca, u skladu s naravi i vrstom posla te ovlašćuje poslodavca na pobliže određivanje mjesta i načina njegova obavljanja (čl. 13., st. 5.). U skladu s navedenim, sve tri bitne odrednice: naplatnost, subordinacija i osobna činidba rada (dobrovoljnost se predmnijeva), prisutne su u radu preko studentskog ugovora. ${ }^{7}$

\footnotetext{
7 Ipak, iz zakonskog uređenja proizlaze snažne karakteristike prekarnosti studentskog rada te studentima ne pripada radnopravna i socijalna zaštita analogno radnom odnosu. Plaćeni su prema broju odrađenih sati rada, a ne prema ugovorenoj mjesečnoj plaći, ne rade prema unaprijed određenom radnom vremenu, ne ostvaruju pravo na plaćeni godišnji odmor, naknadu plaće za vrijeme bolesti, ne postoji zaštita od jednostranog otkazivanja studentskog ugovora i dr. Upravo su fleksibilnost i prekarnost studentskog rada te nepostojanje zaštitnih mehanizama protiv njegove zlouporabe jedne od glavnih karakteristika koje utječu na njegovu isplativost i atraktivnost poslodavcima, a tome valja dodati i značajna fiskalna oslobođenja takvog rada (vidi detaljnije u 6. poglavlju).
} 
Pritom je $\mathrm{u}$ potpunosti zanemareno značenje pojma studenta $\mathrm{u}$ materijalnom smislu, kao osobe koja studira te je u prvom redu dužna voditi računa o svojim akademskim obvezama. Opravdanje iznesene tvrdnje proizlazi iz činjenice da je sklapanje studentskog ugovora omogućeno studentu koji je u protekloj akademskoj godini ostvario najmanje 1 ECTS bod (što se ne primjenjuje na studenta koji je upisao prvu godinu ili je u prethodnoj imao opravdani prekid studija) (ZOSP, čl. 10., st. 3-4.). Nameće se pitanje je li student koji je u akademskoj godini ostvario 1 ECTS bod te pritom radio nekoliko sati dnevno doista student ili radnik?

U svjetlu navedenoga valja razmotriti i novinu uvedenu ZOSP-om (čl. 2., t. 1.) u odnosu prema ranijem uređenju: otvaranje mogućnosti studentskoga rada izvanrednim studentima. Dok se status redovitog studenta temelji na punom nastavnom opterećenju te mogućnosti djelomičnog ili cjelovitog financiranja troškova studijskog programa iz državnog proračuna, status izvanrednog studenta temelji se na pohađanju nastave uz rad ili drugu aktivnost iz čega proizlazi nužnost prilagođenih termina i načina izvođenja studija, a troškove takvog studija u cijelosti ili dijelom snosi student (ZZDVO, čl. 86.). Izvanredni se studenti u hrvatskom visokom školstvu ,smatraju studentima s polovicom studentskog opterećenja odnosno part-time studentima, koji se razlikuju od redovnih studenata po tome što nemaju iste obveze pohađanja nastave, te im, pošto su zaposleni, nisu potrebne subvencije države." Ne uzimajući u obzir obrazovna postignuća dužni su plaćati punu školarinu, ne ostvaruju prava na financijske potpore kao redoviti studenti, nemaju prava na stipendije ni većinu neizravnih potpora poput zdravstvenog osiguranja, studentskog smještaja, troškova prehrane i sl. (Bežovan et al., 2019: 497).

Upravo je ideja izvanrednog studiranja da student uz (prilagođeni) studij radi temeljem ugovora o radu te po završetku studija, u zamjenu za plaćanje pune školarine, neovisno o akademskom uspjehu, raspolaže s nekoliko godina radnog iskustva i mirovinskog staža; ali i da se omogući nastavak formalnog obrazovanja bez prekida karijere. Ovakvo zakonsko uređenje, kratkoročno višom zaradom koju mogu ostvariti temeljem studentskog ugovora, oduzima izvanrednim studentima svojevrsnu komparativnu prednost po završetku studija, koja bi im pripadala da su dio studija istovremeno proveli u radnom odnosu. Pritom je omogućavanjem studentskog rada izvanrednih studenata proširena mogućnost prikrivanja radnog odnosa studentskim ugovorom, osobito uzimajući u obzir jednu od navedenih svrha izvanrednog studija: nastavak formalnog obrazovanja bez prekida radnog odnosa. Postoji opasnost da se umjesto nastavka karijere uz povratak formalnom obrazovanju, formalno obrazovanje nastavi upravo u svrhu da bi se radni odnos određenih kategorija radnika „prikrio“ putem studentskog ugovora i oslobodio fiskalnih opterećenja radnoga odnosa. Naposljetku, takvo rješenje predstavlja opasnost po ostvarenje načela ZOSP-a, definiranih u prethodnom poglavlju: unaprjeđenja studentskog standarda uz sprječavanje poremećaja tržišta rada i ugrožavanja prava radnika. Uzmu li se u obzir podaci Državnog zavoda za statistiku prema kojem je od 158.016 ukupno upisanih 
studenata na visoka učilišta u ak. god. 2018./2019., 114.681 redoviti student (Zwirn Periš, Jurić, Kurjaković \& Šojat, 2020: 30) proizlazi kako je ZOSP-om 43.335 izvanrednih studenata pripušteno tržištu studentskog rada, što predstavlja potencijalnu opasnost poremećaja tržišta rada u cjelini.

Proizlazi kako rad putem studentskog ugovora sadržava bitne elemente radnog odnosa te ne treba a priori isključiti primjenu čl. 10., st. 1. ZR-a na ovakvu vrstu ugovora, imajući u vidu navedeno i činjenicu da studentski ugovor može poslužiti prikrivanju radnog odnosa ${ }^{8}$ (osobito uzimajući u obzir nisko postavljene uvjete da bi se netko prema ZOSP-u smatrao studentom, isplativost takve vrste rada za poslodavca te mogućnost trenutačno veće zarade studenta, a što proizlazi iz fiskalnog tretmana studentskog rada). Pri prosuđivanju radi li se doista o studentskom ugovoru ili o fingiranom pravnom odnosu s ciljem prikrivanja radnog odnosa, prvenstveno valja imati na umu činjenicu da je status studenta zaposlenog temeljem studentskog ugovora podredan studentskom statusu (bez obzira radi li se o redovitom ili izvanrednom studentu, jer se u potonjem slučaju ne radi o izvanrednom studentu u radnom odnosu, već prvenstveno o studentu zaposlenom preko studentskog ugovora).

U svakom potencijalnom predmetu sud bi trebao, vodeći se načelom prvenstva činjenica, tj. sadržaja odnosa (detaljnije vidi Senčur Peček \& Laleta, 2018: 421-423), cijeniti činjenicu trajanja i količine rada i ekonomski značaj tako stečene zarade. Ukoliko se radi o povremenim i, s ekonomskog gledišta, beznačajnim prihodima, tada je nedvojbeno riječ o studentskom ugovoru. Ukoliko su takvi prihodi značajni za egzistenciju te se rad obavlja kontinuirano kroz određeno razdoblje (pri čemu ne treba biti od značaja bi li prosječni broj sati rada odgovarao radu u punom ili nepunom radnom vremenu), tada valja uzeti u obzir mogućnost iz čl. 10., st. 1. ZR-a. Ako sud zaključi da se radi o inverznoj situaciji u kojoj je svojstvo studenta podređeno svojstvu radnika, sud bi trebao pribjeći mogućnosti „prevođenja“ fingiranog studentskog ugovora u ugovor o radu. ${ }^{9}$

\footnotetext{
${ }^{8}$ Usporedbe radi, Laleta i Senčur Peček (2017: 325-326) navode kako je u Sloveniji studentima određena minimalna bruto satnica (kao i u RH od donošenja ZOSP-a, op. a.), ali i da su uključeni u obvezno mirovinsko i invalidsko osiguranje te da se, iako se ne radi o radnom odnosu, na studentski rad primjenjuju odredbe ,o zabrani diskriminacije, jednakom postupanju bez obzira na spol, o radnom vremenu, odmorima i dopustima (...) kao i regulativa o sigurnosti i zaštiti na radnom mjestu“. Uz to ističu kako su postojali slučajevi, gdje je rad studenata ispunjavao elemente radnog odnosa, ,u kojima su studenti uspješno dokazali da su 'posloprimci'“‘. Tako iz prakse slovenskih sudova danas proizlazi kako se status studenta i radnika pojmovno ne isključuju (Senčur Peček \& Laleta, 2018: 435 i bilj. 133 na istoj str.).

${ }^{9} \mathrm{U}$ tom bi smislu trebalo poticati i djelovanje inspekcije rada na utvrđivanje, prilikom provođenja nadzora, prikrivaju li se kod poslodavca radni odnosi studentskim ugovorima. Više o inspekciji rada u RH vidi u Senčur Peček \& Laleta (2018: 431-433).
} 


\section{ODNOS POJMA „RADNIK“ U PRAKSI SUDA EUROPSKE UNIJE I POJMA STUDENTA (IZVOĐAČA) DEFINIRANOG ZOSP-om}

Regulacijske ovlasti EU u pogledu radnoga prava postoje u onim aspektima u kojima je ovlaštena na harmonizaciju nacionalnih radnih prava, ponajprije u odredbama Ugovora o funkcioniranju Europske unije (u nastavku: UFEU) o socijalnoj politici, u pogledu kojih može donositi propise iz područja zaštite na radu, uvjeta rada, zaštite radnika od prestanka ugovora o radu i dr., u skladu s čl. 153., st. 1. UFEU-a, uz isključenje mogućnosti uređivanja pitanja prava na plaću, udruživanje, štrajk i isključenje s rada (UFEU, čl. 153., st. 5.). Pritom provođenje harmonizacije nacionalnih radnih prava, u skladu s ovlastima, EU provodi fragmentarno, u odnosu na samo pojedine institute radnog prava. (Gotovac \& Grgić, 2016: 951).

Radi zaštite prava radnika definiranih aktima EU, presudnim se nameće poznavanje sadržaja pojma „radnik“ u europskom pravu. Odlučujuća uloga pri njegovu definiranju pripada Sudu EU koji stvara standarde i osigurava jednakost tumačenja i primjene europskog zakonodavstva $\mathrm{u}$ pogledu pojma radnika $\mathrm{u}$ državama članicama. Relativno uska definicija pojma radnika u ZR-u (čl. 4., st. 1.) stoga je podložna tumačenju u svjetlu europskoga prava prilikom primjene direktiva i europskih akata kojima je cilj ostvarenje bolje i učinkovitije zaštite radnika. Pritom Osnivački ugovori ni sekundarno zakonodavstvo ne sadrže definiciju pojma radnika, već je njegov sadržaj izveden kroz judikaturu Suda EU koji ga je izgrađivao postupno, proširujući njegov sadržaj te pritom ostavljajući utvrđivanje činjeničnog stanja nacionalnim sudovima, kojima pripada konačna odluka o dodjeljivanju statusa radnika „u skladu s europskim pravom i kriterijima utvrđenim od strane Suda EU.“ (Peročević, 2017: 324-325). Stav Suda EU je da se, ukoliko nacionalni zakonodavac nije direktivom izrijekom ovlašten definirati sadržaj pojma radnika, radi o pojmu europskog prava u pogledu kojega nacionalni pravni poredci nisu nadležni. Nasuprot tome, ukoliko direktiva prepusti državama članicama određivanje pojma radnik i tada ostaje potreba njegova tumačenja u svjetlu europskoga prava u mjeri potrebnoj za ostvarenje ciljeva direktive (Peročević, 2017: 325-326).

Europski pojam radnika izgrađen je ponajprije u odnosu prema slobodi kretanja radnika ${ }^{10}$ prema čl. 45. UFEU-a te se $u$ tom smislu ključnim za postojanje radnoga odnosa smatra ispunjenje uvjeta iznesenih u presudi LawrieBlum, a koji predmnijevaju da je posrijedi ekonomska aktivnost, s elementima subordinacije, tj. obavljanja poslova prema uputama i pod nadzorom poslodavca te naplatnosti (Damjanović, 2013; Bačić \& Sarić, 2014: 33-34; Hasanagić, 2014: 312; Peročević, 2017: 328-329; Senčur Peček \& Laleta, 2018: 426-427). Već je ranije, u predmetu Levin, Sud EU zauzeo stav da je pojam radnika potrebno

\footnotetext{
${ }^{10} \mathrm{U}$ tom je smislu Sud EU u predmetu Hoekstra pridržao isključivo pravo definiranja pojma radnika i ostalih povezanih pojmova „ključnih za utvrđivanje dosega slobode kretanja radnika“ (Bačić \& Sarić, 2014: 33; vidi i Peročević, 2017: 323-324).
} 
široko tumačiti; kako motiv traženja zaposlenja nije od značaja ako se radi o obavljanju stvarne ekonomske aktivnosti; te je pojmom radnika obuhvatio i osobe zaposlene u nepunom radnom vremenu. U predmetu Kempf proširio je pojam radnika na osobe koje rade $\mathrm{u}$ nepunom radnom vremenu te zbog nedostatnih prihoda primaju socijalnu pomoć, određujući kako potonja činjenica ne može biti diskvalificirajući faktor u odnosu prema pravilima o slobodi kretanja radnika. U predmetu Steymann utvrdio je kako oblik naknade za rad (u novcu ili naravi), ukoliko uistinu predstavlja naknadu za ekonomsku aktivnost, nije od značaja pri utvrđivanju postojanja radnog odnosa. Da su pojmom obuhvaćene i osobe koje obavljaju povremene poslove (radnici po pozivu) potvrdio je u predmetu Raulin, određujući trajanje zaposlenja i pripravnost na poziv poslodavca kriterijima procjene. Presudom Trojani istaknuo je da sui generis priroda radnog odnosa prema nacionalnim pravilima, razina produktivnosti, ograničena razina naknade te izvori iz kojih se isplaćuje, nisu mjerodavni pri utvrđivanju svojstva radnika prema europskom pravu. Presudom Ninni-Orasche potvrdio je da motiv i svrha rada ne utječu na statusno određenje radnika, a kao mjerodavne kriterije istaknuo sate rada i naknadu za rad te ga proširio i na osobu zaposlenu temeljem ugovora na određeno vrijeme. Naposljetku, presudom u predmetu Raccanelli pojmom radnika obuhvaćen je i doktorand-stipendist, ukoliko u određenom vremenu prema uputama druge osobe obavlja posao te za njega prima naknadu (detaljnije vidi Damjanović, 2013; Bačić \& Sarić, 2014: 33-35; Hasanagić, 2014: 312-313; Peročević, 2017: 327-330 i 332).

Isprva je Sud EU oklijevao koristiti tako definiran pojam radnika (ponajprije prema formuli Lawrie-Blum) u klasičnim pitanjima radnoga prava definiranim direktivama. Ipak, posljednjih ga je godina počeo koristiti pri tumačenju direktiva koje definiranje pojma radnika ne ostavljaju nacionalnim zakonodavstvima, ali je, u skladu s odlukom u predmetu Betriebsrat der Ruhrlandklinik, europski pojam radnika počeo širiti i na direktive koje eksplicite upućuju na pojam radnika u skladu s nacionalnim zakonodavstvima (Senčur Peček \& Laleta, 2018: 428). U pogledu zaštite prava radnika zajamčenih direktivama važna je presuda u predmetu Dita Danosa u kojem je (Court of Justice of the European Union, 2010: t. 39), za potrebu ostvarenja prava iz Direktive Vijeća 92/85/EEZ od 19. listopada 1992. o uvođenju mjera za poticanje poboljšanja sigurnosti $i$ zdravlja na radu trudnih radnica te radnica koje su nedavno rodile ili doje, potvrdio kako se za svrhe navedene direktive pojam radnika ne može tumačiti prema nacionalnom zakonodavstvu, tj. kako ga treba tumačiti uniformno u skladu s pravom EU te da (t. 41) formalna kategorizacija osobe kao samozaposlene prema nacionalnom pravu ne isključuje mogućnost da ta osoba, za svrhe navedene direktive, bude smatrana radnikom prema europskom pravu, ako je samostalnost takve osobe tek prividna.

Naposljetku, valja spomenuti recentnu presudu u predmetu Matzak u kojem je Sud EU (2018: t. 28-31) odredio da u svrhu primjene Direktive 2003/88/EZ Europskog parlamenta i Vijeća od 4. studenoga 2003. o određenim vidovima organizacije radnog vremena (u nastavku: Direktiva 2003/88/EZ), 
pojam radnika treba tumačiti u skladu s pravom EU te je istim obuhvaćena $\mathrm{i}$ osoba dobrovoljnog vatrogasca s obzirom „,da je imenovani primljen u vatrogasnu službu grada Nivellesa u kojoj je obavljao određene stvarne i učinkovite djelatnosti pod vodstvom druge osobe, za koje je bio plaćen" (t. 31). Presuda Matzak posebno je zanimljiva u usporedbi sa studentom zaposlenim preko studentskog ugovora, s obzirom da je hrvatski zakonodavac propustio zaštititi studente od pretjeranog rada time što ZOSP ne sadržava odredbe o najduljem radnom vremenu (Trbojević, 2018: 15-16). Valja smatrati kako minimalna jamstva sadržana Direktivom 2003/88/EZ treba proširiti i na osobe zaposlene temeljem studentskog ugovora te im time pružiti makar minimalnu zaštitu od pretjeranog rada.

Evidentno je kako iz prakse Suda EU proizlazi znatno širi sadržaj pojma radnik u odnosu prema većini nacionalnih zakonodavstava (uključujući hrvatsko) te se može zaključiti kako je „,[p]ojam radnika uvjetovan činjenicom da mora biti riječ o stvarnoj i istinskoj aktivnosti, a ne o marginalnom i pomoćnom poslu“ (Peročević 2017: 337) te se radnikom smatra „svaka osoba koja obavlja ekonomske aktivnosti na učinkovit i stvaran način uz isključenje aktivnosti od malog značaja koje se tretiraju kao isključivo beznačajne i sekundarne. Bitni elementi za određivanje može li se određena osoba smatrati radnikom su (...) da osoba za određeno vremensko razdoblje obavlja određenu djelatnost za drugu osobu i prema njezinim uputama te zauzvrat dobiva naknadu za rad“ (Damjanović, 2013).

Za očekivati je kako bi Sud EU povodom prethodnog pitanja bio sklon, zavisno o činjenicama pojedinog slučaja, a što je na nacionalnom sudu da utvrdi, proširiti pojam radnika i na studenta zaposlenog prema ZOSP-u (ako bi njegov rad sadržajno odgovarao pojmu radnika prema europskom pravu) te mu pružiti zaštitu prava radnika sadržanu u europskim propisima. Nacionalni sudovi, u potencijalnim bi postupcima trebali voditi računa o europskom pojmu radnika te, ukoliko ne bi bili skloni „prevesti“ studentski ugovor (kojim se prikriva radni odnos) u ugovor o radu prema čl. 10., st. 1. ZR-a, tada bi takav pravni odnos trebali tumačiti u svjetlu europskog prava i pružiti studentu njime zajamčene minimalne standarde zaštite.

\section{PROBLEMATIKA FISKALNOG TRETMANA STUDENTSKOG RADA I LATENTNA PRIJETNJA POREMEĆAJA TRŽIŠTA RADA}

Za potrebe razreza poreza na dohodak iznos primitaka preko studentskog ugovora do 15.000 kuna na godišnjoj razini je neoporeziv (Zakon o porezu na dohodak, u nastavku: ZPD, čl. 9., st. 1., t. 6.; Pravilnik o porezu na dohodak, u nastavku: PPD, čl. 6., st. 1., R. br. 2.) te se do tog iznosa student ne prestaje 
smatrati uzdržavanom osobom. ${ }^{11}$ Primici iznad tog iznosa, nakon odbijanja osnovnog osobnog odbitka (za obveznika) koji od 1. siječnja 2020. godine iznosi 4.000 kuna na mjesečnoj (ZPD, čl. 14., st. 3.), tj. 48.000 kuna na godišnjoj razini, podliježu poreznoj obvezi poreza na dohodak kao tzv. drugi dohodak (ZPD, čl. 39., st. 3., t. 7.; PPD, čl. 52., st. 5.). Proizlazi kako je 63.000 kuna studentskih primitaka na godišnjoj razini oslobođeno poreza na dohodak. Pritom studentski primici nisu opterećeni obveznim doprinosima iz plaće, a poslodavac (naručitelj posla) ne snosi puni teret obveznih doprinosa na plaću, već dvije naknade posredniku koje se računaju kao $12 \%$, odnosno $0,5 \%$ neto naknade izvođaču, tj. studentu (ZOSP, čl. 12., st. 1., t. 3-4. i st. 4.), a koje je posrednik dužan namjenski koristiti za poboljšanje studentskog standarda te u svrhu financiranja kulturnih, sportskih, znanstvenih i edukacijskih aktivnosti studenata i studentskih organizacija (ZOSP, čl. 14, st. 2.-3.). Dodatno, poslodavac snosi konačni teret plaćanja $5 \%$ doprinosa za mirovinsko osiguranje na temelju generacijske solidarnosti u određenim okolnostima i $0,5 \%$ za zdravstveno osiguranje za slučaj ozljede na radu i profesionalne bolesti (Zakon o doprinosima, u nastavku: ZD, čl. 10., st. 1., t. 1.; čl. 13., st. 1., t. 2.; čl. 14., st. 1., t. 4.; čl. 160.; Zakon o mirovinskom osiguranju, čl. 19., st. 1.; Zakon o obveznom zdravstvenom osiguranju, čl. 16., st. 1., t. 1.). Osnovicu dvaju doprinosa čini svaki pojedinačni primitak isplaćen za rad studenta (ZD, čl. 161.), a iako je formalno obveznik njihova obračuna i plaćanja posrednik (ZD, čl. 159.) ZOSP (čl. 12., st. 5.) kao lex specialis prebacuje konačni teret njihova snošenja na poslodavca (naručitelja posla). Pritom je ostvarenje prava iz takvog režima mirovinskog osiguranja ,u određenim okolnostima“" usko vezano uz posebne okolnosti (slučaj invalidnosti i tjelesnog oštećenja zbog ozljede na radu ili profesionalne bolesti) te studenti ne stječu druga mirovinska prava (Vukorepa, Tomić \& Stubbs, 2017: 12).

Opravdanost izražene bojazni kako će ovakvo zakonsko uređenje obavljanja studentskih poslova rezultirati poremećajima tržišta rada, pritom potencijalno ugrožavajući socijalno najosjetljivije skupine radnika, proizlazi iz usporedbe fiskalnog tretmana studentskog, naspram nesamostalnog rada (koji predstavlja najčešći oblik zaposlenja upravo tih skupina). Naime, ukupni primici zaposlene osobe na osnovi nesamostalnog rada podliježu plaćanju obveznih doprinosa iz plaće (ZPD, čl. 23.) u ukupnom iznosu od $20 \%$ (ZD, čl. 13., st. 1., t. 1-1.2.; čl. 17., st. 1., t. 1.) te se tek od tako umanjenog iznosa oduzima iznos osnovnog osobnog odbitka za obveznika (ZPD, čl. 14., st. 3.) kako bi se dobila porezna osnovica poreza na dohodak. Nakon plaćanja poreza na dohodak (i prireza) iznos preostao od osnovice, uvećan za (ranije izdvojen) iznos osnovnog osobnog odbitka, predstavlja raspoloživi (tzv. neto) dohodak radnika zaposlenog po osnovi nesamostalnog rada. Iz navedenoga proizlazi kako, ne samo da je

\footnotetext{
${ }^{11}$ Roditelj (uzdržavatelj) do iznosa od 15.000 kuna usporedno zadržava pravo na uvećanje osnovnog osobnog odbitka za uzdržavanog studenta, a koje gubi tek ako student ostvari primitke veće od navedenog iznosa na godišnjoj razini (ZPD, čl. 17.) te je time stvorena mogućnost dvostrukog oslobođenja od poreza na dohodak, ako prihodi studenta ne prijeđu 15.000 kuna u kalendarskoj godini, isti su dakako neoporezovani, ali roditelju također ostaje pravo uvećanja osnovnog osobnog odbitka za uzdržavanog studenta temeljem čl. 14. ZPD-a.
} 
godišnji neoporezivi iznos takvog radnika 15.000 kuna manji od neoporezivog iznosa studenta, već se osnovni osobni odbitak oduzima od dohotka radnika tek nakon plaćanja obveznih doprinosa za mirovinsko osiguranje, što znači da je ukupan raspoloživi dohodak radnika potencijalno znatno manji od raspoloživog dohotka studenta za istu količinu rada.

Pritom, pri zapošljavanju studenata, poslodavca (naručitelja posla) ne tereti obveza plaćanja obveznog doprinosa na plaću od $16,5 \%$ za obvezno zdravstveno osiguranje (ZD, čl. 14., st. 1., t. 1.) već ranije spomenute naknade posredniku od $12 \%$, odnosno $0,5 \%$ i doprinosi od $5 \%$, odnosno $0,5 \%$. Navedena oslobođenja studentskih primitaka od obveze plaćanja doprinosa iz plaće te poreza na dohodak (i prireza) otvaraju mogućnost kompenzacije poslodavčevih dodatnih troškova temeljem obveznih naknada i doprinosa (u ukupnom iznosu od $18 \%$ na iznos isplaćen studentu), čineći rad studenata daleko isplativijim. Nadalje, proizlazi kako je studentski rad ujedno atraktivniji poslodavcu i zbog činjenice da studenta može zaposliti sukladno potrebi te ga platiti prema količini odrađenih sati rada (a ne prema ugovorenoj mjesečnoj plaći) te pritom ne postoje zakonske zapreke ili uvjeti jednostranom otkazivanju studentskog ugovora, kao što je slučaj kod ugovora o radu (ZR, čl. 115). Pritom svojevrsna zaštitna klauzula sadržana u ZOSP-u (čl. 13., st. 6.), prema kojoj poslodavac koji je poslovno uvjetovanim otkazom otkazao radniku ne smije šest mjeseci od dana dostave odluke o otkazu za tu vrstu poslova sa studentom (izvođačem) sklopiti ugovor o obavljanju studentskih poslova, predstavlja slabu zaštitu radnika.

$\mathrm{S}$ obzirom na nisku povezanost uplaćenih doprinosa mirovinskog osiguranja i visine mirovine, ${ }^{12}$ razvidno je kako bi mnogim radnicima zaposlenima na radnim mjestima s niskim primanjima, koja zahtijevaju nižu razinu stručne kvalifikacije, bilo isplativije upisati visoko učilište (isprva, potencijalno kao redoviti studenti, a potom kao izvanredni studenti na visokom učilištu s relativno niskom školarinom) ${ }^{13}$ te obavljati isti ili sličan posao preko studentskog ugovora, ostvarujući veći iznos ukupnog raspoloživog dohotka, pritom kasnije ne gubeći puno na strani prava iz mirovinskog osiguranja (u sustavu generacijske solidarnosti, dok bi osjetili manjak uplaćenih doprinosa u sustavu individualne kapitalizirane štednje). S obzirom na spomenuti nisko postavljeni uvjet da bi se nekoga smatralo studentom (prvi upis ili 1 ECTS bod) nije nezamisliv upravo takav razvoj događaja. Moguće je zamisliti dva usporedna

\footnotetext{
${ }^{12}$ Redistributivan element (solidarnosti) snažno je prisutan u hrvatskom mirovinskom sustavu, osobito u sustavu generacijske solidarnosti, tzv. prvom stupu (European Commission, 2018b: 106-107). Vukorepa (2015: 291) iz postojanja raznih skupina privilegiranih umirovljenika te umirovljenika čija je mirovina dijelom implicitno subvencionirana $(u$ obliku minimalne mirovine, prijevremene mirovine, obiteljske mirovine i dr.) zaključuje kako ,znatno više od polovice umirovljenika prima višu mirovinu od aktuarski neutralne" te kako hrvatski mirovinski sustav karakterizira snažan redistributivni karakter.

${ }^{13}$ Pritom ZOSP (čl. 10., st. 5.) sadržava relativno blago ograničenje prema kojem ,,[p]osrednik ne može posredovati za studenta koji je dva puta promijenio studijski program i treći puta upisuje prvu godinu iste razine."
} 
učinka ZOSP-a: pretvaranje studenata u radnike mogućnošću značajne zarade iz perspektive studentskog budžeta, a nauštrb redovitog ispunjenja studentskih obveza te uključivanje značajnog broja osoba u sustav visokog obrazovanja, ne radi obrazovanja, već radi stjecanja zarade.

Naposljetku, treba uzeti u obzir i činjenicu da je zakonodavac, s ciljem zaustavljanja odljeva „mladih osoba i visokoobrazovanog mladog kadra iz zemlje“" (Božina, Jurić, Markota, Vuk \& Guzić, 2019: 30), od 1. siječnja 2020. godine osobe do 25 godina života, koje ostvare dohodak temeljem nesamostalnog rada, oslobodio plaćanja poreza na dohodak za dio porezne osnovice oporezive stopom od $24 \%$ tj. do 360.000 kuna godišnje. Dok se godišnji porez na dohodak osoba od 26 do 30 godina života umanjuje za 50 \% razmjernog dijela porezne obveze obračunate na dio porezne osnovice na koju se plaća porez na dohodak po stopi od $24 \%$, tj. do 360.000 kuna (ZPD, čl. 46., st. 2.). Pritom valja spomenuti oslobođenje plaćanja obveznih doprinosa na plaću na strani poslodavca do godine dana za osiguranika koji se prvi put zapošljava (ZD, čl. 20., st. 2.-3.) te do pet godina za osiguranika mladu osobu ${ }^{14}$ (ZD, čl. 20. st. 4.-5.), kombinacijom kojih poslodavac, koji zaposli mladu osobu bez radnog iskustva temeljem ugovora o radu na određeno vrijeme do godine dana, a nakon isteka tog ugovora s istom osobom sklopi ugovor o radu na neodređeno vrijeme, može biti oslobođen troškova doprinosa na plaću do ukupno šest godina (Opalić, 2019: 58). Iz navedenog proizlazi vođenje zakonodavca demografskim ciljevima te iako oni nedvojbeno pripadaju spektru nefiskalnih ciljeva porezne i fiskalne politike (Opalić, 2019: 56), valja biti na oprezu kako se takve demografske mjere prema zaposlenim mladima (kao i socijalni ciljevi ZOSP-a i povezanog fiskalnog zakonodavstva prema studentima) ne bi pokazale nesocijalnima prema starijim zaposlenim osobama.

Pritom su oslobođenja studentskog rada i nesamostalnog rada mladih osoba do 25, odnosno 30 godina života od poreza na dohodak, u odnosu prema dohotku starijih radnika s nižim prihodima, praktično manjeg značaja, s obzirom na relativno visoko postavljen iznos osnovnog osobnog odbitka (za obveznika) te mogućnosti njegova uvećanja (ZPD, čl. 14.), a što nerijetko rezultira potpunim oslobođenjem poreza na dohodak siromašnijih radnika. Ono što primarno čini rad studenata isplativijim i atraktivnijim poslodavcu proizlazi iz prethodne rasprave o karakteristikama fleksibilnosti i prekarnosti studentskog rada, opisanih oslobođenja od obveznih doprinosa te spomenute mogućnosti kompenzacije naknada posredniku i posebnih doprinosa za osiguranja „u određenim okolnostima“" koji terete poslodavca.

\footnotetext{
${ }^{14}$ Mlada osoba je ,fizička osoba koju poslodavac po osnovi ugovora o radu sklopljenog na neodređeno vrijeme prijavljuje na obvezno mirovinsko osiguranje i obvezno zdravstveno osiguranje te do dana početka osiguranja ima manje od 30 godina života, a do dana sklapanja ugovora o radu nije imala prethodno sklopljen ugovor o radu na neodređeno vrijeme s istim poslodavcem" (ZD, čl. 7., t. 54.).
} 


\section{SOCIJALNI KARAKTER UREĐENJA STUDENTSKOG RADA U REPUBLICI HRVATSKOJ}

Želja za unaprjeđenjem studentskog standarda nedvojbeno proizlazi iz zahtjeva socijalne pravednosti te treba predstavljati važan dio cjelovite državne i europske politike prema mladima. Politike poboljšanja materijalnog statusa studenata mogu djelovati stimulirajuće na mlade koji se ne obrazuju (a istovremeno su neaktivni na tržištu rada) da uđu u sustav visokog obrazovanja. Jednako tako mogu potaknuti zaposlene mlade na daljnje obrazovanje u svrhu osobnog i poslovnog napredovanja te unaprjeđenja vlastitog socioekonomskog statusa. S time na umu, valja se zapitati je li normativni okvir studentskog rada doista socijalna mjera ili je posrijedi mimikrija liberalizacije tržišta rada nauštrb socijalnih vrijednosti.

Porezni sustav, kao dio državne fiskalne politike, pretpostavka je ostvarenja njezinih zadaća, od kojih je ostvarenje socijalne pravde utkano u samu bit moderne hrvatske države. Iz navedenoga proizlazi nepotrebnost iznalaženja opravdanja ubiranju poreza (Jelčić, Lončarić-Horvat, Śimović, Arbutina \& Mijatović, 2008: 102). Hrvatski je ustavotvorac postavio određena ograničenja zakonodavcu prilikom uređenja porezne materije. Ta su ograničenja sadržana u zahtjevu sudjelovanja sviju u podmirenju javnih izdataka u skladu sa svojim gospodarskim mogućnostima te $u$ ustavnim načelima porezne jednakosti $i$ pravednosti (URH, čl. 51.). Isticanjem sudjelovanja u podmirenju javnih troškova $\mathrm{u}$ skladu s ekonomskom snagom konstitucionaliziran je zahtjev vertikalne pravednosti, dok načelo jednakosti u sebi sadrži zahtjev vodoravne pravednosti te se isključivo porezni sustav koji je u skladu s takvim ustavnim zahtjevima može smatrati pravednim. Time je naglašena predanost hrvatskog ustavotvorca socijalnoj dimenziji oporezivanja kao jedinoj eksplicite poustavljenoj vrijednosti hrvatskog poreznog sustava (Arbutina, 2012: 1287-1288). Arbutina (2012: 1288) zaključuje kako iz toga proizlazi činjenica „najveće važnosti socijalne osjetljivosti kao ključnog razloga kad je riječ o oporezivanju.“

Uzme li se navedeno u obzir, evidentno je kako URH ostavlja normativnu slobodu zakonodavcu da određene iznose i vrste prihoda, djelomično ili u potpunosti, oslobodi porezne obveze. Štoviše, nameće mu dužnost ostvarenja socijalne pravde, pritom mu pružajući slobodu odabira konkretnih oblika njezine realizacije. Uvažavajući takvu zakonodavčevu slobodu, valja primijetiti kako se izloženi režim poreznog tretmana studentskih prihoda ne može opravdati namjerom unaprjeđenja razine socijalne pravednosti. Studentska populacija previše je heterogena te nisu svi njezini pripadnici socijalno ugroženi. Tome u prilog govori i činjenica da u RH gotovo ne postoji razlika u nejednakosti dohodaka studentske, u odnosu prema općoj populaciji (Gwosć, 2019). Valja zaključiti kako ne postoji opravdan razlog uvođenja dodatnih 15.000 kuna godišnjeg neoporezivog iznosa koji, ionako isplativiji studentski rad, čini daleko jeftinijim od rada iz radnog odnosa te bi potencijalno trebalo razmisliti o uvođenju mogućnosti povremenog rada svih građana (po uzoru na mini-poslove u 
Njemačkoj, vidi u nastavku), uz neoporezivi iznos tako ostvarenih primitaka u istoj visini.

S obzirom da studenti slabijeg socioekonomskog statusa češće rade kako bi podmirili troškove studiranja, ${ }^{15}$ što im ujedno smanjuje šansu završetka studija uslijed vremenske preopterećenosti, valjalo bi razmisliti o unaprjeđenju sustava izravnih potpora studentima, koje ujedno mogu biti dizajnirane upravo u svrhu poboljšanja standarda socijalno ugroženih pripadnika studentske populacije. Takve se potpore razlikuju prema tome jesu li ih studenti u budućnosti dužni vratiti (zajmovi) ili ne (stipendije, školarine i sl.). Sustav bespovratnih potpora poput stipendija temelji se na ideji opće društvene dobrobiti od povećanja udjela visokoobrazovanih te jačanja demokracije i socijalne kohezije. Javni zajmovi s druge se strane temelje na ideji najveće individualne koristi koju pojedinac ostvaruje višim stupnjem obrazovanja te mu se postavlja zahtjev da u budućnosti snosi troškove obrazovanja temeljem kojeg je stekao takvu korist. Nužno je istaknuti kako javni zajmovi mogu odvratiti mlade slabijeg socioekonomskog statusa od upisa na fakultet zbog straha od visokih dugova koje bi u budućnosti mogli snositi. Stoga ne čudi što u većini zemalja EUROSTUDENT-a bespovratne potpore prednjače pred zajmovima. Tako je preko $90 \%$ javnih potpora u RH bespovratno (Gwosć \& Hauschildt, 2016). Povećanje broja i iznosa takvih potpora, uz oporezivanje studentskoga rada analogno poreznom tretmanu nesamostalnog rada, omogućilo bi veću razinu posvećenosti studenata predmetu njihova studija, a osiguralo da oni koji rade pridonose podmirenju javnih izdataka.

Snažniji porezni tretman studentskog rada pridonio bi smanjenju njegove atraktivnosti u odnosu prema radnom odnosu te bi se time uklonili negativni efekti proizišli iz zakonodavčeva zanemarivanja drugog ustavnog prava - prava na rad (URH, čl. 55., st. 1.) i zaradu kojom zaposleni može osigurati sebi i svojoj obitelji slobodan i dostojan život (URH, čl. 56., st. 1.). Pravo na rad predstavlja programsko pravo te ne rezultira neposrednim subjektivnim pravom pojedinca koje bi bilo ostvarivo sudskim putem (Ravnić, 2004: 108). Ono upućuje obvezu zakonodavcu na kreiranje i unaprjeđenje uvjeta i mogućnosti u kojima građani mogu ostvarivati pravo na rad (Jelušić, 2010: 20). Iako ne jamči individualno pravo zaposlenja, u sebi sadrži pravo i slobodu ,poduzimanja privrednih i drugih gospodarskih djelatnosti u punoj slobodi i pod jednakim uvjetima s ostalim građanima“ (Smerdel, 2013: 340). Polazeći od izloženih potencijalno negativnih

\footnotetext{
${ }^{15}$ Ovdje treba podsjetiti kako se na iznos naknade studentu obračunavaju naknade posredniku (ZOSP, čl. 12., st. 1., t. 3.-4.) namijenjene poboljšanju studentskog standarda te financiranju kulturnih, sportskih, znanstvenih i edukacijskih aktivnosti koje provode studenti i studentske udruge (ZOSP, čl. 14., st. 2.-3.) te se postavlja pitanje pravednosti raspodjele tereta troškova ostvarenja tih ciljeva. Jer, iako se naknade posredniku obračunavaju na iznos (neto) naknade studenta (izvođača) te naplaćuju od poslodavca (naručitelja) (ZOSP, čl. 12., st. 4.-5.), iz činjenice da češće rade studenti slabijeg socio-ekonomskog statusa proizlazi kako će veći dio tereta poboljšanja studentskog standarda i ostvarenja drugih navedenih ciljeva (od čega korist imaju svi studenti) biti naplaćen na iznos naknada za rad siromašnijih studenata. Stoga bi trebalo razmisliti o mogućnosti da se navedeni, nedvojbeno legitimni ciljevi, financiraju iz državnog proračuna, a što bi pridonijelo ostvarenju pravednosti transparentnosti.
} 
efekata, koje bi aktualno uređenje studentskog rada moglo imati po tržište rada u cjelini, upitno je koliko se zakonodavac vodio zahtjevima proizišlim iz ustavnog prava na rad prilikom donošenja ZOSP-a i povezanog fiskalnog zakonodavstva.

U tom smislu valja razmotriti trenutni fiskalni tretman studentskog rada te porezne olakšice pri oporezivanju dohotka od nesamostalnog rada osoba do 25 , odnosno 30 godina života i navedene fiskalne olakšice poslodavcima pri zapošljavanju mladih osoba i osoba koje se prvi put zapošljavaju, a koje njihov rad čine isplativijim te potencijalno atraktivnijim od rada starijih radnika. Osobito je tako u pogledu rada putem studentskog ugovora, s obzirom na činjenicu da je isti moguće otkazati bez ograničenja iz ZR-a, a pritom poslodavac studente zapošljava u skladu s potrebom te ih plaća prema količini odrađenih sati rada, a ne prema ugovorenoj mjesečnoj plaći. Stoga bi, ne osporavajući zakonodavčevo pravo da, u svrhu ostvarenja raznovrsnih ciljeva socijalne, ekonomske i demografske politike, uspostavi iznimke od ustavne obveze sviju na pridonošenje podmirenju javnih potreba sukladno ekonomskoj snazi poreznog obveznika (URH, čl. 51., st. 1.), trebalo postaviti pitanje postojanja legitimnog cilja navedenih fiskalnih oslobođenja. Stoga prihvatljivost postizanja socijalnih učinaka prema studentima te demografskih učinaka putem fiskalnih oslobođenja rada mladih osoba, treba ocjenjivati u usporedbi s potencijalnim učincima na starije radnike, temeljem ustavnih načela oporezivanja (URH, čl. 51.) te u duhu ustavnog koncepta socijalne države (čl. 1., st. 1.) i načela socijalne pravde (čl. 3.).

Kao odgovor na neke od iznesenih kritika, potencijalno bi socijalne ciljeve posebnog uređenja studentskog rada trebalo proširiti po uzoru na „marginalni rad s nepunim radnim vremenom“, tzv. mini-poslove (engl. minijobs) koji u Njemačkoj postoje više desetljeća te su 60-ih i 70-ih godina prošloga stoljeća korišteni radi povećanja ponude rada, a nakon tzv. Hartzove reforme 2003. godine prvenstveno radi prevladavanja/ublažavanja visoke nezaposlenosti (European Commission, 2018a: 10-11). Za kvalifikaciju određenog zaposlenja kao mini-posla važno je da mjesečna naknada ne prelazi određeni iznos (450 eura). Ranije je postojalo najdulje tjedno radno vrijeme (15 sati), koje je ukinuto. Osoba pritom može obavljati mini-posao kao jedini ili kao dodatni posao. Tako zaposleni radnici s osnove mini-posla ne ostvaruju pravo na zdravstveno osiguranje, niti osiguranje za slučaj nezaposlenosti, a obvezno mirovinsko osiguranje uvedeno je tek 2013. godine, s time da radnik može zahtijevati oslobođenje od te obveze (engl. opt-out), dok poslodavca terete paušalni doprinosi za zdravstveno i mirovinsko osiguranje te paušalni iznos poreza na plaću. Posebno se uspješnom pokazala mogućnost kumulacije mini-poslova sa socijalnom potporom u obliku zajamčene plaće (Laleta \& Bodiroga-Vukobrat, 2016: 56-58). Mini-poslove obavljaju umirovljenici, kućanice, nezaposleni, učenici, studenti, osobe kojima je to jedini izvor prihoda te zaposlene osobe kojima predstavlja dodatan izvor zarade. Pritom se mogućnost obavljanja miniposlova ističe posebno zanimljivom osobama koje su zdravstveno osigurane po drugoj osnovi (European Commission, 2018a: 15). Relativno je velik udio učenika i studenata u obavljanju mini-poslova te su im atraktivni s obzirom da su 
zdravstveno osigurani temeljem osiguranja roditelja ili kao studenti. Također, studentima je pod određenim uvjetima dozvoljeno kombiniranje mini-poslova (do 450 eura mjesečno) i privremenog zaposlenja poput stažiranja (engl. internship) bez da ih se smatra ovisnim zaposlenima i obveznicima doprinosa za socijalno osiguranje (European Commission, 2018a: 21). Uvođenjem sličnog uređenja u hrvatski pravni sustav studentima se ne bi oduzela mogućnost rada uz studij pod posebnim uvjetima, već bi isti uvjeti bili prošireni na sve građane. Dakako, i u takvo bi uređenje valjalo ugraditi zaštitne mehanizme u obliku ograničenja moguće zarade i tjednih/mjesečnih sati rada, kako socijalni cilj ne bi u stvarnosti proizveo neželjene učinke za ranjive skupine radnika u radnom odnosu. Sadašnji godišnji neoporezivi iznos studentskog rada od 15.000 kuna mogao bi se time proširiti na sve građane, a ujedno bi se isti iznos moglo odrediti i kao najviši dopušteni godišnji iznos primitaka temeljem takvog marginalnog povremenog rada.

Zaključno, iako je klasični model socijalne države, zasnovan na stabilnom radu kao temelju ekonomske ovisnosti i socijalne sigurnosti, izgubio na uvjerljivosti (Puljiz, Bežovan, Šućur \& Zrinščak, 2005: 266), evidentno je kako studentski rad ne smije biti sredstvom prevladavanja socijalnih problema mladih. Trbojević (2018: 15-16) s pravom ističe kako je ishodište ZOSP-a ,prilično dubiozan i suspektan koncept uređenja tržišta rada“ te kako studentski rad ne smije postati sredstvo smanjenja troškova poslovanja kroz smanjenje troškova rada. „Studiranje nije $\mathrm{i}$ ne bi trebala biti socijalna mjera za zbrinjavanje nezaposlenih...".

\section{ZAKLJUČAK}

Unaprjeđenje socio-ekonomskog položaja mladih predstavlja jedan od temeljnih izazova suvremene socijalne politike EU i država članica. Dio mladih usporedno je dio sustava obrazovanja i tržišta rada te proizlazi kako rad uz studij predstavlja važan izvor prihoda u svrhu nastavka i završetka studija zaposlenih studenata. Takav rad istovremeno prijeti smanjenjem mogućnosti završetka studija, oduzimajući studentima vrijeme potrebno za izvršavanje studentskih obveza.

Hrvatski je zakonodavac koncem 2018. godine uzdigao uređenje studentskog rada na zakonsku razinu. Iako je zakonodavčeva namjera, ogledana kroz implicite sadržana načela, nedvojbeno socijalna, promatrano normativno rješenje prijeti proizvesti krajnje nesocijalne učinke. Takvo zakonsko uređenje je studenta (izvođača) definiralo kao prekarnog radnika, ostavljajući ga bez pravne zaštite koja bi mu pripadala ako bi isti rad obavljao temeljem radnog odnosa. Time je otvorena mogućnost prikrivanja radnog odnosa (isplativijim) studentskim ugovorom. Stoga ne treba a priori isključiti mogućnost „prevođenja“ takvog pravnog odnosa u radni odnos temeljem čl. 10., st. 1. ZR-a. Također, iz usporedbe uređenja studentskog rada s pojmom radnika u judikaturi Suda EU, valja zaključiti kako bi pod određenim okolnostima student zaposlen temeljem studentskog ugovora mogao potpadati pod europsku definiciju radnika te bi tada imao pravo na minimalnu zaštitu radničkih prava zajamčenu pravom EU. 
Promotreno s aspekta povezanih fiskalnih propisa, pretjerano blagim poreznim opterećenjem studentskog dohotka otvorena je mogućnost trenutno veće zarade u odnosu prema onoj iz radnog odnosa te su pritom smanjeni troškovi poslodavcu koji je ujedno oslobođen mjera zaštite radnika sadržanih u ZR-u. Time su otvorena vrata iskorištavanju sustava studentskog rada te potencijalnim poremećajima tržišta rada u cjelini.

Valja zaključiti da regulacija studentskog rada ZOSP-om (zajedno s povezanim fiskalnim propisima) nije uspjela osigurati ostvarenje implicite sadržanih načela: unaprjeđenje studentskog standarda uz sprječavanje poremećaja tržišta rada. U takvim okolnostima treba preispitati potrebu posebnog uređenja studentskog rada (te njegova potencijalnog ukidanja ${ }^{16}$ i proširivanja mogućnosti povremenog rada po posebnim uvjetima, po uzoru na tzv. mini-poslove $u$ Njemačkoj, na sve građane). Prihvati li se gledište prema kojem studentski rad predstavlja socijalnu mjeru s ciljem poboljšanja studentskog standarda, tada je mogućnost takvog rada potrebno redefinirati kako bi doista uspio u ostvarenju proklamiranog cilja, ne izazivajući pritom poremećaje na tržištu rada. Najvažnije bi izmjene trebale uključivati: definiranje najvišeg dozvoljenog radnog vremena studenata, ukidanje dodatnih 15.000 kuna neoporezivog iznosa studentskog dohotka, ${ }^{17}$ potencijalno proširivanje određenih prava i standarda zaštite radnika iz radnog i socijalnog zakonodavstva na studente zaposlene prema ZOSP-u i dr. Naposljetku, trebalo bi ponovno (pr)ocijeniti novouvedenu mogućnost rada izvanrednih studenata temeljem studentskog ugovora.

Takve izmjene, upotpunjene financijskim potporama studentima slabijeg socioekonomskog statusa, trebaju predstavljati polazišnu točku pri ispunjenju nedvojbeno legitimnog cilja: poboljšanja studentskog standarda u svrhu ostvarenja socijalne pravednosti, ne dovodeći u pitanje pravedno postupanje prema ostalim dionicima tržišta rada.

\section{LITERATURA}

Arbutina, H. (2012). Ustavna i nadnacionalna ograničenja ovlaštenja na oporezivanje. Zbornik Pravnog fakulteta u Zagrebu, Vol. 62, No. 5-6, pp. 1283-1322.

Bačić, P., Sarić, I. (2014). Kratka studija aktivizma europskog suda kroz presude o slobodi kretanja radnika. Zbornik radova Pravnog fakulteta u Splitu, Vol. 51, No. 1, pp. 27-44. https://doi.org/10.31141/zrpfs.2018.55.127.221

\footnotetext{
${ }^{16}$ Tada bi sredstva od naknada za posredovanje (ZOSP, čl. 12., st. 1., t. 3.-4.), koja je posrednik dužan namjenski koristiti za poboljšanje studentskog standarda te u svrhu financiranja kulturnih, sportskih, znanstvenih i edukacijskih aktivnosti koje isključivo provode studenti i studentske organizacije (ZOSP, čl. 14., st. 2.-3.), trebalo osigurati u državnom proračunu.

${ }^{17}$ Ako se zadrži sadašnje posebno uređenje studentskog rada. Ukoliko se umjesto toga uvede mogućnost povremenog rada ograničenog trajanja i/ili do ograničenog iznosa tako ostvarenih primitaka, tada bi se 15.000 kuna neoporezivog iznosa moglo uzeti kao najviši godišnji iznos takvih primitaka, a koji bi uz to bio neoporeziv.
} 
Bežovan, G., Puljiz, V., Šućur, Z., Babić, Z., Dobrotić, I., Matković, T., Zrinščak, S. (2019). Socijalna politika Hrvatske (2. izdanje). Zagreb: Pravni fakultet Sveučilišta u Zagrebu.

Božina, A., Jurić, Đ., Markota, Lj., Vuk, J., Guzić, Š. (2019). Porezne novosti u primjeni od 1. siječnja 2020. godine. Računovodstvo, revizija i financije, No. 12, pp. 20-36.

Butković, H., Samardžija, V., Skazlić, I., Čavar, I. (2018). Nestandardni rad u Hrvatskoj: izazovi i perspektive u odabranim sektorima. Zagreb: IRMO - Institut za razvoj i međunarodne odnose. https://doi.org/10.3326/ao.2017.99

Cindori, S., Kuzelj, V. (2019). Exemplis discimus: Reafirmacija vrijednosti i redefinicija sadržaja socijalne države u novom stoljeću. Zbornik Pravnog fakulteta Sveučilišta u Rijeci, Vol. 40, No. 2, pp. 823-843. https://doi.org/10.30925/zpfsr.40.2.7

Court of Justice of the European Union (2010). Judgement of the Court (Second Chamber) in Case C-232/09 Dita Danosa v LKB Lìzings SIA, 11 November 2010.

Čavar, I. (2018). Student employment: characteristics and effects of its use in Croatia. Interdisciplinary Description of Complex Systems, Vol. 16, No. 1, pp. 60-70. https://doi.org/10.7906/indecs.16.1.4

Damjanović, D. (2013). Definiranje pojma „radnik“ u europskom pravu. IUS-INFO, 26. lipnja 2013., http://www.iusinfo.hr/DailyContent/Topical.aspx?id=15901 (7. 5. 2020.).

Direktiva Vijeća (92/85/EEZ) od 19. listopada 1992. o uvođenju mjera za poticanje poboljšanja sigurnosti i zdravlja na radu trudnih radnica te radnica koje su nedavno rodile ili doje (SL, posebno izdanje na hrvatskom jeziku, 05/Vol. 4, pp. 73 - 80.).

Direktiva (2003/88/EZ) Europskog parlamenta i Vijeća od 4. studenoga 2003. o određenim vidovima organizacije radnog vremena (SL, posebno izdanje na hrvatskom jeziku 05/Vol. 2, pp. 31-41).

European Commission (2018a). Case study - gaps in access to social protection for mini-jobs in Germany. Luxembourg: Publications Office of the European Union.

European Commission (2018b). The 2018 Pension Adequacy Report: current and future income adequacy in old age in the EU, Country profiles, Volume II. Luxembourg: Publications Office of the European Union.

EUROSTUDENT, https://www.eurostudent.eu/about (24. 12. 2019.).

EUROSTUDENT VI Database: http://database.eurostudent.eu/ (16. 5. 2020.).

Gotovac, V., Grgić, A. (2016). Radni odnosi u presudama Suda Europske unije. Pravo u gospodarstvu, Vol. 55, No. 5, pp. 947-984.

Gwosć, C. (2019). Income Inequality Among Students in European Higher Education, Eurostudent Intelligence Brief, 1/2019, https://www.eurostudent. eu/publications (7. 12. 2019.).

Gwosć, C., Hauschildt, K. (2016). The Structure of Public Student Support in Europe, Eurostudent Intelligence Brief, 3/2016, https://www.eurostudent.eu/publications (7. 12. 2019.).

Hasanagić, E. (2014). Utjecaj prakse Suda Evropske unije na ostvarivanje slobode kretanja radnika. Pravni vjesnik, Vol. 30, No. 2, pp. 307-327. 
Hauschildt, K. Vögtle, E. M., Gwosć, C. (2018). Social and Economic Conditions of Student Life in Europe: EUROSTUDENT VI 2016-2018 Synopsis of Indicators. Bielefeld: W. Bertelsmann Verlag GmbH \& Co. KG, doi:10.3278/6001920cw

Herman, V., Ćupurdija, M. (2011). Osnove radnog prava (elektronsko izdanje). Osijek: Sveučilište Josipa Jurja Strossmayera u Osijeku, https://www.pravos.unios .hr/pfo/sites/default/files/RadnoiSocijalno/knjiga-osnove_radnog_prava.pdf (12. 5. 2020.). https://doi.org/10.24869/psihei.2020.276 11 , pp. 3-6.

Iljazović, B. (2018). Novine u reguliranju studentskih poslova. Radno pravo, No.

Jelčić, B., Lončarić-Horvat, O., Šimović, J., Arbutina, H., Mijatović, N. (2008). Financijsko pravo i financijska znanost. Zagreb: Narodne novine.

Jelušić, M. (2010). Socijalna prava u Ustavu Republike Hrvatske, In: BodirogaVukobrat, N., Barić, S. (eds.). Socijalna prava kao temeljna ljudska prava. Zagreb: TIM press/Zaklada Sveučilišta u Rijeci, pp. 19-29. https://doi.org/10.22182/sp.12019.1

Laleta, S., Bodiroga-Vukobrat, N. (2016). Fleksigurnost i (de)regulacija tržišta rada. Zbornik Pravnog fakulteta Sveučilišta u Rijeci, Vol. 37, No. 1, pp. 33-69. https://doi.org/10.30925/zpfsr.37.1.2

Laleta, S., Senčur Peček, D. (2017). Atipični rad - izazovi zaštite od psihosocijalnih rizika i stresa na radu i u vezi s radom. Sigurnost, Vol. 59, No. 4, pp. 315-330. https://doi.org/10.31306/s.59.4.1

Milković, D. (2016). Ugovor o radu i zakon o obveznim odnosima. Zbornik Pravnog fakulteta Sveučilišta u Rijeci, Vol. 37, No. 1, pp. 685-713. https://doi.org/10.30925/zpfsr.37.1.24

Obadić, A. (2017). Nezaposlenost mladih i usklađenost obrazovnog sustava s potrebama tržišta rada. Ekonomska misao i praksa, Vol. 26, No. 2, pp. 129-150.

Oertelè, Ž. (2019). Motives and Benefits of Working While Studying, Eurostudent Intelligence Brief, 5/2019, https://www.eurostudent.eu/publications (7. 12. 2019.). 12, pp. 65-67.

Opalić, D. (2018). Novi zakon o studentskom radu. Pravo i porezi, Vol. 28, No.

Opalić, D. (2019). Utjecaj izmjena propisa o porezu na dohodak i obveznim doprinosima na tržište rada u Republici Hrvatskoj. Računovodstvo i financije, No. 7, pp. 56-58. https://doi.org/10.3326/nlh.2012.68

Peročević, K. (2017). Pojam „radnika“ u pravu Europske unije. Zbornik Pravnog fakulteta u Zagrebu, Vol. 67, No. 2, pp. 319-343. https://doi.org/10.3935/zpfz.70.23.04

Potočnjak, Ž., Gotovac, V. (2009). Rad i pravni oblici rada u Republici Hrvatskoj, In: Franičević, V., Puljiz, V. (eds.). Rad u Hrvatskoj: pred izazovima budućnosti. Zagreb: Centar za demokraciju i pravo Miko Tripalo/Pravni fakultet Sveučilišta u Zagrebu, pp. 277-301. https://doi.org/10.3935/rsp.v17i1.910

Pravilnik o porezu na dohodak (»Narodne novine«, broj 10/17., 128/17., 106/18., 1/19., 80/19. i 1/20.).

Pravilnik o posredovanju pri zapošljavanju redovitih studenata (»Narodne novine«, broj 16/96., 125/97., 37/06., 59/07. i 30/08.). 
Puljiz, V.; Bežovan, G.; Šućur, Z.; Zrinščak, S., Socijalna politika - Povijest, sustavi, pojmovnik, Zagreb: Pravni fakultet Sveučilišta u Zagrebu, 2005.

Ravnić, A. (2004). Osnove radnog prava - domaćeg, usporednog $i$ međunarodnog. Zagreb: Pravni fakultet $\mathrm{u}$ Zagrebu.

Senčur Peček, D., Laleta, S. (2018). Ugovor o radu i ugovor o djelu: područje primjene radnoga zakonodavstva. Zbornik Pravnog fakulteta Sveučilišta u Rijeci, Vol. 39, No. 1, pp. 411-456. https://doi.org/10.30925/zpfsr.39.1.14

Smerdel, B., Sokol, S. (2009). Ustavno pravo, Zagreb: Narodne novine.

Smerdel, B. (2013). Ustavno uređenje europske Hrvatske. Zagreb: Narodne novine.

Sud Europske unije (2018). Presuda Suda (peto vijeće) u predmetu C-518/15 Ville de Nivelles protiv Rudyja Matzaka, 21. veljače 2018. 12, pp. 9-16.

Trbojević, G. (2018). Zakon o obavljanju studentskih poslova. Radno pravo, No.

Ugovor o funkcioniranju Europske unije (pročišćena verzija) (SL 2016/C 202/1, Vol. 59, pp. 47-200).

Ustav Republike Hrvatske (»Narodne novine«, broj 56/90., 135/97., 8/98. pročišćeni tekst, 113/00., 124/00. - pročišćeni tekst, 28/01., 41/01. - pročišćeni tekst, 55/01. - ispravak, 76/10., 85/10. - pročišćeni tekst i 5/14.).

Vidović, A. (2018). Rad studenata prema novom Zakonu. Računovodstvo, revizija i financije, Vol. 28, No. 12, pp. 230-235.

Vukorepa, I. (2015). Lost between Sustainability and Adequacy: Critical Analysis of the Croatian Pension System's Parametric Reform. Revija za socijalnu politiku, Vol. 22, No. 3, pp. 279-308. https://doi.org/10.3935/rsp.v22i3.1307

Vukorepa, I., Tomić, I., Stubbs, P. (2017). ESPN Thematic Report on Access to social protection of people working as self-employed or on non-standard contracts: Croatia. Brussels: European Commission: Directorate-General for Employment, Social Affairs and Inclusion, https://ec.europa.eu/social/main.jsp?pager.offset=30\&adv SearchKey $=$ ESPNsensw $\&$ mode $=$ advancedSubmit $\&$ catId $=22 \&$ policyArea $=0 \&$ policyAreaS $\mathrm{ub}=0$ \& country $=0$ \&year $=0(24.12 .2019$. $)$.

Zakon o doprinosima (»Narodne novine«, broj 84/08., 152/08., 94/09., 18/11., 22/12., 144/12., 148/13., 41/14., 143/14., 115/16. i 106/18.).

Zakon o mirovinskom osiguranju (»Narodne novine«, broj 157/13., 151/14., 33/15., 93/15., 120/16., 18/18., 62/18., 115/18. i 102/19.). 16/20.).

Zakon o obavljanju studentskih poslova (»Narodne novine«, broj 96/18. i

Zakon o obveznim odnosima (»Narodne novine«, broj 35/05., 41/08., 125/11., 78/15. i 29/18.).

Zakon o obveznom zdravstvenom osiguranju (»Narodne novine«, broj 80/13., 137/13. i 98/19.).

Zakon o porezu na dohodak (»Narodne novine«, broj 115/16., 106/18., 121/19. i $32 / 20$.). 
Zakon o radu (»Narodne novine«, broj 93/14., 127/17., 98/19.).

Zakon o znanstvenoj djelatnosti i visokom obrazovanju (»Narodne novine«, broj 123/03., 198/03., 105/04., 174/04., 02/07., 46/07., 45/09., 63/11., 94/13., 139/13., 101/14., 60/15., 131/17.).

Zlatović, D., Galić, A. (2018). Novi pravni okvir uređenja obavljanja studentskih poslova u Republici Hrvatskoj. Zbornik radova Veleučilišta u Šibeniku, No. 3-4, pp. 65-81.

Zlatović, D., Malenica, I. (2016). Razlika ugovora o radu od drugih ugovora s prestacijom rada. Radno pravo, No. 3, pp. 24-32.

Zwirn Periš, Ž., Jurić, J., Kurjaković, D., Šojat, A. (2020). Studenti u akademskoj godini 2018./2019. Statistička izvješća. Zagreb: Državni zavod za statistiku Republike Hrvatske. 


\title{
Valentino Kuzelj
}

Student

University of Zagreb

Faculty of Law

E-mail: valentino.kuzelj01@gmail.com

\section{SOCIAL CHARACTER OF STUDENT EMPLOYMENT REGULATION IN THE REPUBLIC OF CROATIA}

\begin{abstract}
Most young people participate in the labour market in some form during their education. It is imperative to define clear goals and concrete policies for securing a decent living standard of students enabling them to fulfil their academic duties and finish their studies. Student employment represents an important source of student income in the Republic of Croatia. At the end of 2018 Croatian legislators passed a new law regulating student work. The main purpose of the bill was an improvement of student standard. Although presented as a social measure, it failed to protect students, treating them as precarious workers. At the same time, low fiscal burden of student work made it more attractive and lucrative compared to the work based on the employment contract, threatening to create labour market disruptions. This paper points out concrete problems in the regulation of "student work" in the Republic of Croatia and highlights a need for its redefinition to achieve social justice.
\end{abstract}

Keywords: student employment, worker, labour market, taxation, social justice

JEL classification: $\mathrm{J} 21, \mathrm{~J} 28, \mathrm{~J} 88$ 